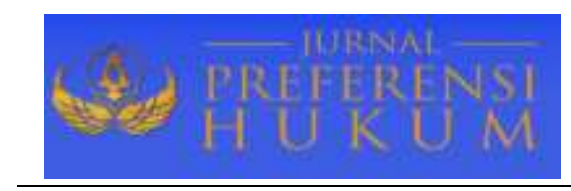

Jurnal Preferensi Hukum | ISSN: XXXX | E-ISSN: XXXX Vol. 1, No. 2 - September 2020, Hal. 93-98| Available Online at https://www.ejournal.warmadewa.ac.id/index.php/juprehum DOI: http:doi.org/10.22225/jph.v1i2.2346.93-98

\title{
MEKANISME PENYELESAIAN SENGKETA INFORMASI PUBLIK DI PENGADILAN TATA USAHA NEGARA DENPASAR
}

\author{
I Made Bayu Ari Budi Utama, Ida Ayu Putu Widiati, Luh Putu Suryani \\ Fakultas Hukum Universitas Warmadewa Denpasar-Bali, Indonesia
}

\begin{abstract}
Abstrak
Keberlangsungan informasi publik adalah aspek yang tidak bisa dipisahkan dari demokrasi yang menjunjung tinggi kebebasan dan hak asasi manusia. Keberlangsungan informasi publik menjadi aspek yang penting dalam hal pemenuhan hak individu atas informasi publik. Namun, dalam prakteknya, pemahaman masyarakat mengenai mekanisme penyelesaian sengketa Keberlangsungan Informasi Publik masih rendah. Selain itu didalam pelaksanaan sengketa Keberlangsungan Informasi Publik ini masih memiliki hambatan yang bisa mengganggu proses pelaksanaan. Yaitu dapat berupa tidak ada kepentingan pemohon untuk memohon informasi dan kurang pahamnya pemohon mengenai proses administratif dalam pelaksanaan sengketa. Berdasarkan permasalahan tersebut, maka adapun tujuan penelitian ini yaitu Mengetahui upaya penyelesaian sengketa informasi publik dan Praktik proses penyelesaian sengketa keberlangsungan informasi publik . Metode penelitian yang digunakan yaitu metode empiris dibantu oleh sumber bahan Hukum Primer dan Sekunder dan memakai teknik kualitatif, yaitu dengan mendeskripsikan data hukum terlebih dulu lalu menganalisa melalui teknik analisis dengan teknik tafsiran dan ditumpahkan secara deskriptif dengan bentuk skripsi. Upaya penyelesaian sengketa informasi publik dapat dilakukan melalui dua proses, yaitu proses non - litigasi yang dilaksanakan di Komisi Informasi Daerah yang berwenang dan proses litigasi yang ditempuh di PTUN andaikata badan publik yang bersengketa adalah badan publik milik Negara atau di PN andai kata Badan publik yang bersengketa adalah badan publik swasta. Dalam praktiknya proses penyelesaian sengketa keberlangsungan informasi di Indonesia masih memiliki hambatan yang dapat berupa salah paham yang diakibatkan oleh kurang pahamnya pemohon informasi terhadap mekanisme permohonan atau tahapan proses administratif yang harus dilalui dalam mengajukan sengketa keberlangsungan informasi publik.
\end{abstract}

Kata Kunci: Mekanisme; Sengketa; Informasi publik

\begin{abstract}
The sustainability of public information is an inseparable aspect of democracy, which upholds freedom and human rights. The sustainability of public information is an important aspect in fulfilling individual rights to public information. However, in practice, the public's understanding of the dispute resolution mechanism on the Sustainability of Public Information is still low. In addition, in the implementation of this Public Information Sustainability dispute, there are still obstacles that can interfere with the implementation process. That can be in the form of the applicant's lack of interest in requesting information and the applicant's lack of understanding of the administrative process in dispute implementation. Based on these problems, the purpose of this study is to know the efforts to resolve public information disputes and practice the process of dispute resolution on the sustainability of public information. The research method used is the empirical method assisted by primary and secondary legal material sources and uses qualitative techniques, namely by describing legal data first, then analyze through analysis techniques with interpretive techniques and shed descriptively in the form of a thesis. Efforts to resolve public information disputes can be carried out through two processes, namely the nonlitigation process carried out at the competent Regional Information Commission and the litigation process undertaken at the State Administrative Court if the disputing public body is a State-owned public agency or a $P N$ if the disputing public body is said. is a private public body. In practice, the process of resolving information sustainability disputes in Indonesia still has obstacles which can be in the form of misunderstandings caused by the applicant's lack of understanding of the application mechanism or the stages of the administrative process that must be passed in filing a dispute on the sustainability of public information.
\end{abstract}

Keywords: Mechanism; Dispute; Public information 


\section{PENDAHULUAN}

Sejak diputuskannya Undang - undang no 14 tahun 2008, peranan Komisi Informasi Daerah ini sangat vital dalam melayani dan memenuhi hak warga untuk memperoleh informasi publik sehingga warga bisa berperan aktif dalam setiap proses perencanaan, pengambilan, pengawasan, evaluasi kebijakan dan masalah-masalah publik lainnya.

Di golongan masyarakat secara umum, keberadaan UU Keberlangsungan Informasi Publik ini masih belum populer. (Amiruddin, 2012), yang merupakan anggota Komisi Informasi Pusat, mengatakan bahwa sosialisasi yg kurang menyebabkan UU Keberlangsungan Informasi Publik belum banyak diakses dan dimanfaatkan masyarakat. Hanya golongan tertentu seperti LSM saja yang menyadari keberadaan dan manfaat UU Keterbukaan Informasi Publik ini (Republika, 2018). Hal ini mengakibatkan masyarakat belum begitu menyadari sepenuhnya soal hak asasi yang dimilikinya untuk mendapatkan informasi publik sebagai wujud keaktifan publik dalam membuat tata pemerintahan yang baik. Lebih-lebih kepada masyarakat daerah yang masih minim fasilitas teknologi komunikasi dan informasi serta jauh dari pusat pemerintahan.

Terkait dengan penelitian terdahulu oleh (Prasetyo, 2016) menyatakan bahwa Penyelesaian sengketa serta proses ajudikasi litigasi diatur oleh Undang-Undang Nomor 14 Tahun 2008 tentang Keterbukaan Informasi Publik dan PERMA RI Nomor 2 Tahun 2011 tentang Tata Cara Penyelesaian Sengketa Informasi Publik di Pengadilan. Kendala yang terjadi dalam penyelesaian SIP di PTUN adalah putusan Komisi Informasi sebagai obyek gugatan serta badan hukum publik dapat menjadi penggugat di PTUN.

Permasalahan-permasalahan yang ada pada saat proses pelaksanaan UU Keberlangsungan Informasi Publik di suatu daerah memiliki perbedaan dengan daerah lainnya. Karena setiap daerah mempunyai beraneka ragam dan kekhasan masing-masing. Baik dari aspek karakteristik masyarakat, kepemimpinan, budaya birokrasi, sosial ekonomi, ketersediaan teknologi komunikasi dan informasi, dan lainnya.

Maka sesuai hal - hal yang dijelaskan tersebut, penulis menginginkan untuk membuat penelitian terhadap Mekanisme Penyelesaian Sengketa Informasi Publik di Pengadilan Tata Usaha Negara Denpasar dan Praktik proses penyelesaian sengketa keberlangsungan informasi publik.

\section{METODE PENELITIAN}

Penelitian ini menggunakan tipe penelitian empiris yang disebut juga dengan penelitian sosiologis. Alasan penulis menggunakan tipe penelitian ini karena pangkal tolak penelitian secara langsung meneliti mekanisme dan hambatan - hambatan. Tipe penelitian ini merupakan penelitian yang berfokus pada masalah yang meneliti masalah didasarkan pada praktek di masyarakat. Dari sudut ilmu yang digunakan dalam penelitian ini bersifat monodispliner dalam artian bahwa ada satu disiplin ilmu yang digunakan yaitu ilmu hukum. Pendekatan masalah dalam penelitian ini dilakukan dengan mempergunakan metode pendekatan Sosiologi Hukum. Sumber data yang digunakan dalam penelitian ini adalah sumber data primer dan sekunder.

Dalam membahas Prosedur Penyelesaian Sengketa Keberlangsungan Informasi Publik di PTUN Denpasar ini memakai sumber bahan Hukum. Sumber bahan Hukum yang dipakai didalam penelitian meliputi : Data Primer yang diperoleh dari narasumber pertama dengan melakukan wawancara informan yang terkait penelitian ini yaitu Hakim Pengadilan Tata Usaha Negara Denpasar. Dan Data Sekunder yang didapat dari pengkajian kepustakaan, meliputi bahan - bahan Hukum yang bekaitan dengan penelitian ini yaitu: Undang - Undang Dasar Negara Republik Indonesia Tahun 1945, UU No 5 Tahun 1986 Tentang Peradilan Tata Usaha Negara, UU No 14 Tahun 2008 Tentang Keterbukaan Informasi Publik, Peraturan Pemerintah Nomor 61 Tahun 2010 tentang pelaksanaan UU No 14 Tahun 2008 Tentang Keterbukaan Informasi Publik, Peraturan Mahkamah Agung No 2 Tahun 2011 tentang Tata Cara Penyelesaian Sengketa Informasi Publik di Pengadilan, dan Peraturan Komisi Informasi No. 2 Tahun 2010 tentang prosedur penyelesaian sengketa informasi publik.

Dalam mendapatkan data primer, dan sekunder digunakan teknik Wawancara, Observasi, inventarisasi atau penelusuran bahan hukum yang bersangkutan lalu di golongkan atau diklompokan 
dan dicatatat, dikutip, diringkas, diulas sesuai kebutuhan. Penelitian ini dilakukan PTUN Denpasar. Menganalisis penelitian ini memakai teknik kualitatif, yakni dengan menjelaskan data hukum terlebih dahulu kemudian menganalisa melalui teknik analisis dengan teknik tafsiran dan dituangkan secara deskriptif dengan bentuk skripsi.

\section{HASIL DAN PEMBAHASAN}

\section{Prosedur Penyelesaian Sengketa Informasi Publik}

Proses penyelesaian sengketa dapat dilakukan melalui dua proses yaitu melalui proses litigasi didalam pengadilan, lalu berkembang proses penyelesaian sengketa dari kerjasama diluar pengadilan. Proses litigasi memperoleh kesepakatan yang bersifat adversial belum bisa memeluk kepentingan bersama, cenderung menimbulkan masalah baru, lambat dalam penyelesaiannya, memerlukan biaya yang mahal, tidak responsive dan mengakibatkan permusuhan diantara pihak yang bersengketa. Sebaliknya, melalui proses diluar pengadilan mendapatkan hasil kesepakatan yang bersifat win-win solution, diberi jaminan kerahasiaan sengketa para pihak, dijauhi kelambatan yang disebabkan oleh hal procedural dan adminiistratif, mentuntaskan masalah secara kekeluargaan dalam kebersamaan, dan tetap menjaga hubungan baik. Satu - satunya kelebihan proses non - litigasi ini bersifat rahasia, karena proses dan hasil persidangan dan keputusannyapun tidak dipublikasikan. (Adi, 2009; Mashari, 2010).

Mediasi erupakani salah satu jalan alternatif penyelesaian sengketa di Indonesia. Pemakaiannya sudah diintegrasikan kedalam system peradilan kita dan juga diberbagai UU sebagai alternatif menyelesaikan sengketa terutama yang terjadi antara warga dengan negara, diantaranya UU Perlindungan Konsumen, UU Lingkungan Hidup, UU Pelayanan Publik, UU Ketenagakerjaan, UU Keterbukaan Informasi Publik dan lain-lain. Secara umum mediasi memiliki arti proses penyelesaian sengketa antara dua pihak atau lebih dengan cara berunding atau dengan cara mufakat dengan bantuan pihak yang netral yang tidak memiliki kewenangan memutus (Asmawati, 2014; Rahmadi, 2010; Talib, 2013). Setelah mendapatkan kesepakatan, maka, selanjutnya kesepakatan ditumpahkan kedalam bentuk putusan komisi informasi yang bersifat final dan terikat.

Mediasi bersifat tertutup, kecuali para pihak menginginkan lain. Artinya apabila para pihak sendiri tak meminta agar prosesnya dijalankan secara terbuka maka pertemuan-pertemuan dalam proses mediasi selalu akan dijalankan tertutup. Tidak setiap orang bisa mengakses informasi ke ruang mediasi. Begitupun semua yang terjadi dalam ruang mediasi akan dirahasiakan dari akses pihak luar (DY.Wiyanto, 2011).

Dalam mediasi ini, Mediator berupaya kesepakatan agenda dan memimpin proses mediasi untuk mendapat kesepakatan para pihak, dan Mediator sedapat mungkin berupaya penyelesaian sengketa melalui sekali pertemuan.jika, andaikata mediator menilai mediasi tidak cukup dijalankan dalam sekali pertemuan, mediator menetapkan jadwal pelaksanaan mediasi berikutnya sesuai dengan kesepakatan para pihak.

Apabila para pihak sudah sepakat, maka selanjutnya kesepakatan ditumpahkan dengan bentuk putusan komisi informasi yang bersifat final dan mengikat. Proses Ajudikasi oleh Komisi Informasi dapat ditempuh apabila cara mediasi dinyatakan tidak berhasil secara tertulis oleh satu pihak, atau para pihak yang bersengketa keluar dari perundingan. Jadi jelas bahwa meskipun berbeda dengan Peraturan Mahkamah Agung No. 1 Tahun 2008, UU ini mengetahui dan mengatur tentang mediasi (Amriani, 2011). Andaikata proses mediasi dinyatakan gagal, maka, proses penyelesaian sengketa diteruskan ke tahap ajudikasi. Sidang ajudikasi dilaksanakan secara terbuka untuk umum, kecuali dalam hal pemeriksaan-pemeriksaan yang berkaitan dengan dokumen - dokumen yang berhubungan dalam pengecualian sidang dilakukan dengan cara tertutup.Ini dilakukan karena Majelis Komisioner wajib menjaga kerahasiaan dokumen tersebut. Dan dalam proses persidangan ini, Majelis komisioner bersifat aktif. Proses Ajudikasi harus diselesaikan selambat - lambatnya selama 40 hari.

Putusan Majelis Komisioner bersifat mengikat para pihak sejak dibacakan dalam sidang terbuka untuk umum. Andaikata salah satu pihak mengatakan secara tertulis tidak menerima putusan tersebut, maka Majelis Komisioner dapat mengajukan gugatan ke pengadilan pengadilan yg berwenang dalam waktu paling lambat 14 (empat) belas hari sejak putusan diterima.

Ada dua jalur yang disediakan, yaitu melalui Peradilan Umum (PN) atau Peradilan Tata Usaha Negara (PTUN). Yang menentukan jalur yg digunakan adalah status siapa yang digugat. 
Apabila tergugatnya adalah Badan Publik Negara, maka jalurnya melalui PTUN. Sebaliknya jika tergugat adalah Badan Publik non-negara, jalur yg digunakan adalah Peradilan Umum. Pembagian Pengadilan yang berwenang ini di tegaskan dalam Pasal 47 UU Keterbukaan Informasi Publik. Putusan yang dikeluarkan oleh PTUN atas keberatan sengketa informasi bukan tahapan terakhir. Undang-Undang masih memungkinkan para pihak mengajukan kasasi.

\section{Hambatan dalam Penyelesaian Sengketa Informasi Publik}

Undang - undang keterbukaan Informasi publik ( UUKIP ) diharap dapat menjadi alat untuk mencari keadilan bagi masyarakat dalam mendapat haknya yang berupa informasi publik, namun dalam implementasinya ternyata masih terdapat halangan-halangan yang dapat ditemukan

Berdasarkan hasil wawancara yang saya lakukan dengan Bapak Himawan Krisbiantoro, selaku Hakim Pratama Utama di Pengadilan Tata Usaha Negara Denpasar, bahwa menurut beliau salah satu hambatan yang terjadi dalam upaya penyelesaian terdapat pada pemahaman pemohon keberatan terhadap proses administratif dalam pengajuan sengketa keterbukaan informasi publik. Menurut beliau dalam beberapa kasus sengketa keterbukaan informasi publik yang sudah beliau periksa, ada beberapa kasus dimana pemohon keberatan tidak melaksanakan proses administratif penyelesaian sengketa dengan benar. Contohnya dalam beberapa kasus ada beberapa pemohon keberatan yang belum memenuhi prosedur administratif diluar proses pengadilan (non - litigasi) seperti pengajuan dan penyelesaian sengketa di Komisi Informasi Daerah. sedangkan putusan dari Komisi Daerah tersebut adalah salah satu persyaratan wajib yang harus dimiliki oleh pemohon keberatan untuk.

Selain itu, berdasarkan hasil wawancara yang saya lakukan dengan Bapak Gayuh Rahanty yang menjabat sebagai Hakim Pratama Madya Pengadilan Tata Usaha Negara Denpasar menyatakan bahwa, hambatan lain yang terjadi dalam upaya penyelesaian sengketa keterbukaan informasi publik ada pada uji kepentingan pemohon keberatan dalam membuat permohonan informasi publik. Menurut beliau, ada dua penyebab yang dapat menyebabkan hal ini dapat terjadi yaitu, kurangnya pemahaman dari pemohon informasi publik tersebut atau adanya oknum - oknum tertentu yang memanfaatkan celah hukum yang terdapat pada aturan yang berlaku. Menurut beliau aturan yang mengatur upaya penyelesaian sengketa informasi publik masih terdapat celah hukum yang dapat dimanfaatkan oleh para oknum untuk kepentingan pribadinya. Dalam pelaksanaan pemerintahan yang baik (Good Government) sebenarnya pihak pemerintah dan pengadilan Republik Indonesia sudah melakukan upaya - upaya dalam mengantisipasi hambatan - hambatan yang sudah dijelaskan sebelumnya.

Upaya - upaya yang sudah dilakukan diantaranya adalah sudah dibentuknya Komisi Informasi Pusat dan Komisi Informasi Daerah yang tersebar di seluruh daerah di Indonesia. Pembentukan Komisi Informasi ini sudah diamalkan pada Bab IV Undang - undang no 14 Tahun 2008 tentang Keterbukaan Informasi Publik (KIP). Komisi Informasi ini memiliki peran yang penting dan krusial dalam perkembangan Keterbukaan Informasi Publik. Namun pembentukan Komisi informasi inipun mengundang perhatian sejumlah kalangan. Pasalnya, terdapat beberapa dilematika terkait dengan persyaratan dan proses pembentukan Komisi Informasi berdasarkan ketentuan yang diatur di dalam Undang - Undang Keterbukaan Informasi Publik.

Selain sudah dibentuknya Komisi Informasi di sebagian besar daerah di Indonesia, upaya lain yang sudah dilaksanakan oleh pemerintah adalah dengan dibentuknya Peraturan Pemerintah Nomor 61 Tahun 2010 tentang pelaksanaan UU No 14 Tahun 2008 Tentang Keterbukaan Informasi Publik. Tujuan dibentuknya Peraturan Pemerintah Nomor 61 Tahun 2010 ini adalah untuk menetapkan Pengklasifikasian Informasi yang ditetapkan oleh Pejabat Pengelola Informasi dan Dokumentasi (PPID) di setiap Badan Publik berdasarkan Pengujian Konsekuensi secara saksama dan penuh ketelitian sebelum menyatakan Informasi Publik tertentu dikecualikan untuk diakses oleh setiap orang. Dalam pasal 4 ayat (2) Peraturan Pemerintah Nomor 61 Tahun 2010, yang dimaksud pengklasifikasian adalah jenis penggolongan Informasi yang tidak termasuk, identitas PPID yang menetapkan, Badan Publik, termasuk unit kerja pejabat yang menetapkan, Jangka Waktu Pengecualian, alasan pengecualian, dan tempat dan tanggal penetapan. Dengan dibentuk PP Nomor 61 Tahun 2010 ini maka, halangan-halangan yg terjadi didalam kesalah pahaman pengelolaan informasi dan kepentingan pemohon informasi dapat diminimalisirkan. 


\section{SIMPULAN DAN SARAN}

\section{Simpulan}

Penyelesaian Sengketa dalam Keterbukaan Informasi Publik dapat dilakukan melalui dua proses penyelesaian yaitu melalui proses litigasi dan non - litigasi. Proses non litigasi dilakukan di Komisi Informasi publik yang berwenang. Terdapat dua proses penyelesaian sengketa dalam proses non litigasi yaitu proses mediasi dan proses. Proses mediasi dinyatakan berhasil apabila para pihak sepakat untuk berdamai dan menyatakan tidak akan melanjutkan sengketa mereka ketahap selanjutnya, namun apa bila para pihak tidak sepakat untuk berdamai maka proses penyelesaian sengketa dilanjutkan ke tahap ajudikasi.

Tahap ajudikasi dilaksanakan secara terbuka untuk umum dengan menunjuk salah satu pihak dari Komisi Informasi yang berwenang sebagai Ketua dan Anggota Majelis Komisioner yang akan memimpin jalnnya persidangan. ajudikasi. Sedangkan proses litigasi dilakukan di pengadilan yang berwenang. Kewenangan pengadilan ditentukan dari badan publik yang bersengketa. Apabila badan publik yang bersengketa adalah badan publik swasta maka tahapan selanjutnya dilaksanakan di Peradilan umum, namun apabila badan publik yang bersengketa adalah badan publik milik Negara maka tahapan selanjutnya dilaksanakan di Pengadilan Tata Usaha Negara. Proses persidangan menghasilkan Putusan yang dapat berupa membatalkan atau menguatkan putusan Komisi Informasi. Isi putusan bisa dilihat dari jenis sengketa informasinya.Pertama, jika mengenai pemberian atau penolakan akses informasi, maka putusan hakim bisa berupa membatalkan putusan Komisi Informasi dan memerintahkan Badan Publik memberikan informasi yang diminta; atau sebaliknya menguatkan dengan menyatakan putusan Komisi Informasi sudah benar dan tidak bertentangan dengan hukum.Pihak yang tidak setuju dengan hasil putusan Pengadilan Tata Usaha Negara masih memungkinkan untuk melanjutkan proses penyelesaian sengketa dengan mengajukan kasasi.

Ada berbagai hambatan yang dapat ditemukan dalam proses penyelesaian sengketa Keterbukaan Informasi Publik. antara hambatan yg ditemukan dapat terjadi karena kurangnya pemahaman pemohon keberatan terhadap proses administratif dalam pengajuan sengketa keterbukaan informasi publik yang menyebabkan salahnya prosedur penyelesaian yang dilakukan pemohon keberatan. Selain itu, dalam beberapa kasus terdapat juga hambatan yang disebabkan oleh adanya celah hukum yang terdapat pada aturan yang berlaku. Celah ini dapat digunakan oleh oknum oknum untuk mendapatkan informasi - informasi tertentu yang dapat menguntungkan oknum tersebut. Sebenarnya sudah ada beberapa upaya yang dilakukan oleh pemerintah untuk mencegah hambatan - hambatan yang ada, diantaranya adalah dengan membentuk Komisi Informasi dan Membentuk PP No 61 Tahun 2010 tentang pelaksanaan Undang - Undang Nomor 14 Tahun 2008 tentang Keterbukaan Informasi Publik.

\section{Saran}

Sebaiknya pihak pemerintah dapat mensederhanakan mekanisme penyelesaian sengketa keterbukaan informasi publik yang sudah berlaku sekarang. Karena menurut penulis, mekanisme penyelesaian sengketa keterbukaan informasi publik yang sudah berlaku saat ini memakan waktu yang sangat lama dengan proses yang berbelit - belit. Berikutnya ada baiknya memberikan edukasi lebih lanjut kepada masyarakat untuk meningkatkan pemahaman masyarakat mengenai tata cara permohonan informasi dan tata cara pengajuan permasalahan keterbukaan informasi publik yang benar dan baik sesuai dengan UU No 14 Tahun 2008 Tentang Keterbukaan Informasi Publik. 


\section{DAFTAR PUSTAKA}

Adi, S. N. (2009). Mediasi Sebagai Alternatif Penyelesaian Sengketa PT. Telaga Ilmu Indonesia. Amiruddin. (2012). Banyak Warga Indonesia tak Tahu UU KIP dan Manfaatnya. Republika.Co.Id. Amriani, N. (2011). Mediasi Alternatif Penyelesaian Sengketa Perdata di Pengadilan. Grafindo Persada.

Asmawati. (2014). Mediasi Salah Satu Cara dalam Penyelesaian Sengketa Pertanahan. Jurnal Ilmu Hukum.

DY.Wiyanto. (2011). Hukum Acara Mediasi. Alfabeta.

Mashari. (2010). Mekanisme Penyelesaian Sengketahubungan Industrial secara win-Win Solution. $7(2), 188-200$.

Prasetyo, T. (2016). Penyelesaian Sengketa Keterbukaan Informasi Publik di Pengadilan Tata Usaha Negara Semarang. Jurnal Spektrum Hukum, 13(2).

Rahmadi, T. (2010). Mediasi: Penye lesaian Sengketa melalui Pendekatan Mufakat. PT RajaGrafindo Persada.

Talib, I. (2013). Bentuk Putusan Penyelesaian Sengketa Berdasarkan Mediasi. Lex et Societatis, I(1), 39-49. 